\title{
Lisa Palmer
}

Water Politics and Spiritual Ecology, Custom. Environmental Governance and Development. London and New York: Routledge, 2015, xxi + 214 pp. [Routledge Explorations in Environmental Studies]. IS BN 9780415753511. Price: GBP 90.00 (hardback).

Water Politics is a detailed account of the hydro-social ecology in Buncau and Viqueque, Timor Leste. Based on ten years of research the aim of the book is to understand how water is perceived, managed, and used. The study provides an ecological animic account of the local relationship to water. It does so by also focusing on local notions and uses of springs and water ways as well as how people account for these in myths, legends, and more recent historical memory. These relationships with and to water the author calls the 'hydro-social cycle'. Springs are treated as historical subjects and the author shows how spring water continues to play a central role in contestations over power and place. The ethnography brings water into the centre of the study and stresses on the importance of well-springs to the community's wellbeing. Springs provide people with an emplaced identity as it also forms an important part of a people's relationship to non-human and non-physical and religious realities.

In this account, water is one key way of relating to the environment and its unseen non-physical reality. Sacred springs are not just a source of power but portals to that reality. Another concept the author uses is 'inclusive sociality' referring to a mode of being that tries to incorporate exogenous forces through relationships. Again water (the hydro-social cycle) has its part to play in these relationships.

In Buncau, springs were believed to be under the custody of a range of animals, particularly snakes and eels. These animals were believed to have been able to metamorphose into human beings as they would travel on the land searching for new locations for well-springs, before reverting back to their original form. Humans are also said to have emerged out of springs and therefore water is seen as the substance that carries the essence of a shared origin and inclusive sociality of all beings. Another feature of the hydro-social cycle discussed relates to the management of water resources which also played and plays a crucial role in marriage exchange between fertility takers and receivers and older/younger sibling traditions. Marriage between two parties would have linked together their water sources. However, the colonial governments interfered with the house-complex relationship that was clustered around springs and many springs were left unattended and fell into disuse. Another interesting demonstration in the book is the role that the hydro-social cycle played as

(C) NATHAN PORATH, 2016 | DOI: 10.1163/22134379-17202013

This is an open access article distributed under the terms of the Creative Commons 
a resisting force and empowerment against outside threat. One nice account tells of the sudden gushing forth of springs celebrating the land's liberation as Indonesia pulled out of East Timor.

One of the book's aims is not just to present ethnography but to bring awareness of the importance of considering local views and practices relating to water. Parker points out that the formal sector of modern Timor Leste tends to ignore or underestimate the local capacity for economic engagement and this effects policies designed for the area and particularly in relation to water. Hence the author urges outsiders to listen to the storied memories of the local hydro-social cycle because they contain knowledge about the environment and society.

Although the book is a work of ethnography in the conventional sense, it is written with a non-anthropological (non-cultural studies) audience in mind as well. The author adopts the term 'mental imaginaries' from hydroecological studies but never explains what she means. This is the type of term that someone from a biologically-based science or theoretical approach might use to lump together highly complex human phenomena that their discipline cannot theoretically manage. The term 'mental imaginary' in this sense is materially reductionist.

Adding to the semantic and conceptual confusion, the author borrows the term 'spiritual ecologies' from another social science discourse, religious studies. Are we to assume that spiritual ecologies are one type of 'mental imaginary'? The term spiritual ecologies makes assumptions about the nature of spirit that might be unwarranted in the context of animist-based knowledges. The point about animic ways of relating to the environment is that they are not spiritual even as they are spirit-based and we should be careful how we use the term spiritual in animic-based ecological contexts, if we use it at all. Parker's ethnographic account does not provide us with a spiritual ecology. It is an account of a cosmology that recognises seen (physical) and unseen (nonphysical) realities which are quite different from the Western-based knowledge systems that gave us terms like 'mental imaginaries' and 'spiritual ecologies'. Both these concepts are highly problematic for the ethnographic context Parker is describing, because they both grew out of and reflect a knowledge system based on dualism. Parker's ethnography could have been stronger if she elaborated for her non-anthropological readership on the animic ecological concept as developed by anthropologists, and further advanced or challenged the ways the term fits and does not fit in her context. A clearer and more rigorous theoretical grounding on recent theories of animist ontologies might have better served one of the book's chief objectives, namely, to offer readers an ethnographically rich understanding of the local hydro-cycle. 
Water Politics is nicely illustrated with photographs and clear and detailed maps. Each chapter ends with a conclusive discussion and its own bibliography which suggests that each chapter can be bought individually from the publishers. Important for its general subject matter on hydro-ecologies, Water Politics also provides some novel ideas of how to understand the cosmic dimensions of water in human life. With its strengths as well as its shortcomings, this work contributes to hydro-ecological studies, animism and religious studies, orality history and memory, Timor Leste and Southeast Asian Studies.

\section{Nathan Porath}

Center for Ethnic Studies and Development Chiang Mai University, Thailand nathanporath@yahoo.co.uk 